\title{
SURVEILLANCE OF DISEASES IN FARMED PENAEUS VANNAMEI IN THE INDIAN SUNDERBANS
}

\author{
ABRAHAM, T.J. ${ }^{1 *} \&$ PRIYADARSANI, L. ${ }^{2}$ \\ 1. Department of Aquatic Animal Health, Faculty of Fishery Sciences, West Bengal University of \\ Animal and Fishery Sciences, Chakgaria, Kolkata - 700 094, India. \\ 2. Kakdwip Research Centre of ICAR - Central Institute Brackishwater Aquaculture, \\ Kakdwip - 743347, India.
}

*Corresponding author: abrahamtj1@gmail.com

\begin{abstract}
Abraham, T.J. \& Priyadarsani, L. (2019). Surveillance of Diseases in Farmed Penaeus vannamei in the Indian Sunderbans. Braz. J. Aquat. Sci. Technol. 23(1). eISSN 1983-9057. DOI: 14094/bjast.v23n1. Penaeus vannamei farming has been the major aquaculture practice in the Indian Sundarbans. This study investigated the physicochemical characteristics, management practices, distribution of vibrios, and the prevalence of bacterial, parasitic and viral diseases in 14 P. vannamei intensive culture farms in the Indian Sunderbans during 2016. The total heterotrophic counts of the pond water ranged from 3.53 to $6.21 \log _{10} \mathrm{cfu} / \mathrm{ml}$. The presumptive vibrios were in the range of $2.40-4.99 \log _{10} \mathrm{cfu} / \mathrm{ml}$. Mild vibriosis was noted in 3 farms. Twenty out of 21 isolates from the haemolymph samples were confirmed to be Vibrio parahaemolyticus by the PCR amplification of the toxR gene. No acute hepatopancreatic necrosis disease (AHPND) causing $V$. parahaemolyticus ( $V p_{\text {AHPND }}$ ) strain was, however, detected. Of the 14 shrimp farms surveyed, only one farm sample was white spot virus (WSV) positive and all others were negative. All the $P$. vannamei farms were negative for infectious hypodermal and haematopoietic necrosis virus, hepatopancreatic parvo-like virus, and infectious myonecrosis virus. No incidence of Enterocytozoon hepatopenaei, white faecal syndrome, running mortality syndrome, protozoan infestation, and luminous vibriosis was observed during the survey period. The survival rate was $90-95 \%$ in the normal ponds, while the lowest survival was $60 \%$ in an asymptomatic WSV infected farm. The physicochemical characteristics of the farms were well within the optimum, except for the WSV infected farm, which had high ammonia levels. Due to the lack of awareness on the $P$. vannamei farming practices and high operational costs, the biosecurity measures were not strictly followed in the surveyed farms.
\end{abstract}

Key Words: Indian Sundarbans, Penaeus vannamei, viral diseases, AHPND, biosecurity.

\section{INTRODUCTION}

Scientific culture of shrimp started in West Bengal, India during the mid-1980s and by 2010 more than 47,588 ha area was brought under shrimp culture. The development of coastal aquaculture in West Bengal was centred on Peneaus monodon farming until 2015. By 2015, the area under shrimp culture rose to 53,974 ha (MPEDA, 2015). The current aquaculture production of shrimp in West Bengal increased from 26,800 tons in $2001-2002$ to 57369.77 tons in 2014-2015 (MPEDA, 2015). The first setback to the West Bengal shrimp culture industry was in 1996-1997, attributed mainly to the environmental degradation and outbreak of diseases of viral origin (Abraham \& Sasmal, 2008). Several viruses caused diseases in $P$. monodon, P. vannamei, P. stylirostris, Fenneropenaeus indicus, Marsupenaeus japonicus, etc and the average annual economic losses are in the tune of 1 billion US\$ (Claydon et al., 2010; Otta et al., 2014). Vibrio species are among the normal bacterial flora of both natural and cultural populations of shrimp and the culture environment, and many of them are pathogenic to shrimp (Yang et al., 2014; Anandaraja et al., 2017). The early mortality syndrome or acute hepatopancreatic necrosis disease (AHPND) is a newly emergent penaeid shrimp disease that caused serious economic losses in shrimp farms in southern China in 2010 and subsequently in Vietnam, Thailand, and Malaysia (FAO, 2013). The AHPND is caused only by some pathogenic strains of Vibrio parahaemolyticus (Yang etal., 2014). World farmed shrimp production volumes decreased in 2012 and particularly in 2013, mainly as a result of disease-related problems, such as AHPND (FAO, 2014). Difficulties in captive breeding of $P$. monodon could not make it possible for the development of Specific-Pathogen-Free (SPF) and genetically improved stains with disease resistance (Otta et al., 2014). In this context, the SPF strain of Pacific white leg shrimp ( $P$. vannamei) was introduced in India in 2009 , which revived the shrimp culture in India. The production of this species surpassed the production of $P$. monodon owing to its faster growth, compatibility to higher stocking rate, less disease risk, euryhaline as well as eurythermic nature, lower dietary protein requirement and lower feed conversion ratio (Raj et al., 2010; Kumaran et al., 2017). The Coastal Aquaculture Authority of India recommended a stocking rate of up to $60 \mathrm{~m}^{2}$ (Raj et al., 2010). The Sundarbans is a cluster of low-lying islands in the Bay of Bengal, spread across India and Bangladesh, 
famous for its unique mangrove forests. The Indian Sundarbans Delta is part of the delta of the Ganga-Brahmaputra-Meghna basin in Asia. This active delta region is among the largest in the world, measuring about 40,000 km² (Danda et al., 2011). Since 2014-15, the farming of $P$. vannamei has been the major practice in both brackishwater and freshwater areas of West Bengal including the Indian Sunderbans. This study investigated the management practices, physicochemical characteristics, distribution of vibrios, particularly $V$. parahaemolyticus and the prevalence of bacterial, parasitic and viral diseases in select $P$. vannamei farms of the Indian Sunderbans during 2016.

\section{MATERIALS AND METHODS}

\section{Sampling area and sample collection}

The disease surveillance in 14 Penaeus vannamei farms of the Indian Sunderbans located in Amratala, Gangadharpur, and Krishnanagar of South 24 Parganas district $(n=7)$, and Hasnabad, Abad Mohanpur and Paschim Goberia of North 24 Parganas district $(n=7)$, West Bengal, India (Figure 1) was carried out in 2016 as per the OIE guidelines (OIE, 2013).

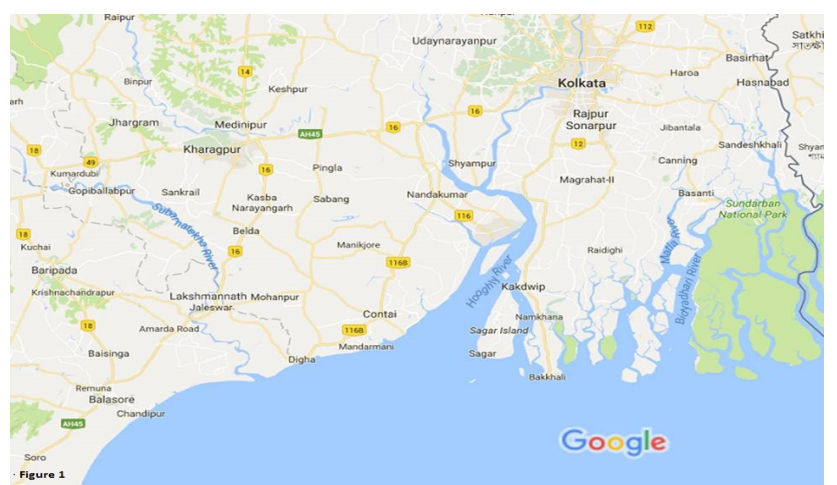

Figure 1 - Google map of the Indian Sunderbans.

The water samples from the column region were collected in sterile $250 \mathrm{ml}$ polypropylene bottles for bacteriology. The samples for water quality parameters were also collected from the column region in 300 $\mathrm{ml}$ glass bottles. All the samples were placed in an insulated container. Healthy and/or diseased $P$. vannamei samples $(\mathrm{n}=10)$ were collected from all the farms, packed separately in oxygen filled polythene bags and brought to the laboratory within $3 \mathrm{~h}$ of collection. The farm management practices were collected from the shrimp farmers at the time of sample collection.

\section{Physicochemical analyses}

The salinity, $\mathrm{pH}$ and dissolved oxygen (DO) were measured by conductivity probe (CDC401), $\mathrm{pH}$ probe (PHC281) and luminescent DO probe, respectively using
Hach multiparameter kit (Hach, Loveland, CO, USA). The levels of ammonia and alkalinity were determined as per APHA/AWWA/WEF (2012).

\section{Enumeration of bacterial counts in pond water}

The spread plate technique was followed for the enumeration of total heterotrophic bacterial counts (THC), luminous bacterial counts (LBC) and presumptive vibrio counts (PVC) from the pond water samples as described earlier (Abraham \& Palaniappan, 2004; Priyadarsani \& Abraham, 2013). Aliquots (0.1 ml) of appropriately diluted water samples were spread on to the tryptone soya agar supplemented with $1 \%$ sodium chloride $(\mathrm{NaCl})$ [TSA], seawater complex (SWC) agar (Ramaiah \& Chandramohan, 1993) and thiosulphate citrate bile salt sucrose agar (TCBS) supplemented with $1 \% \mathrm{NaCl}$ plates in duplicate. The plates were incubated at $30 \pm 2{ }^{\circ} \mathrm{C}$ for $16-48 \mathrm{~h}$. Luminescence on SWC agar was observed in a dark room after $16-20 \mathrm{~h}$ of incubation. The numbers of colonies were counted and expressed as $\log _{10} \mathrm{cfu} / \mathrm{ml}$.

\section{Microscopy}

The microscopic observations for the ectoparasitic infestation on the gills, exoskeleton and appendages are as described in Lightner (1993).

\section{Vibrio isolation from haemolymph and preparation of bacterial lysate}

About $100 \mu \mathrm{l}$ haemolymph was collected from the ventral sinus of each $P$. vannamei using 26 gauge 1 $\mathrm{ml}$ tuberculin syringe, mixed with $10 \mathrm{ml}$ alkaline peptone water (APW) and incubated at $30 \pm 2{ }^{\circ} \mathrm{C}$ overnight. Inocula from APW were streaked onto the TCBS and incubated $30 \pm 2{ }^{\circ} \mathrm{C}$ for $24 \mathrm{~h}$. Representative green colour colonies on TCBS with distinct colony morphology were picked, purified by repeated streaking on TSA and then maintained on TSA soft agar tubes. An aliquot of the haemolymph sample was also streaked on to the SWC agar for the isolation of luminous vibrios. Luminescence was observed in dark after 16-20 h of incubation.

For the preparation of bacterial lysate, the bacterial isolates were first streaked onto the TSA plates to get discrete colonies. The isolated colonies were then transferred to tryptone soya broth with $1 \% \mathrm{NaCl}$ and incubated at $30^{\circ} \mathrm{C}$ separately. The culture broth was centrifuged $\left(7,000 \mathrm{rpm}, 4^{\circ} \mathrm{C}, 10 \mathrm{~min}\right.$, Eppendorf, Germany) to obtain the pellet. The pellet was washed with normal saline $(0.85 \% \mathrm{NaCl} w / v)$ twice, and re-suspended in DNA-free sterile distilled water (180 $\mu l)$. The suspension was boiled for $10 \mathrm{~min}$ in a water bath to lyse the cells, and to release the DNA. The lysate was centrifuged $\left(7,000 \mathrm{rpm}, 4^{\circ} \mathrm{C}, 10 \mathrm{~min}\right)$, and the supernatant was stored at $-20^{\circ} \mathrm{C}$ for further use. 
Identification of Vibrio parahaemolyticus by species-specific toxR gene and detection of Vibrio parahaemolyticus ( $\mathrm{Vp}$ AHPND $)$ strain

The species-specific primers (toxR gene) were used for the identification of $V$. parahaemolyticus strains (Kim et al., 1999). The strains possessing the toxR gene were taken for the detection of $V p{ }_{A H P N D}$ strain (Table 1). The PCR protocol for the amplification of AHPND-AP3 gene was followed for the confirmation of $\mathrm{Vp}_{\mathrm{AHPND}}$ strain (Sirikharin et al., 2014).

\section{Extraction of viral nucleic acid from the pleopods and muscle tissue}

The extraction of viral nucleic acid from the pooled pleopod samples or muscle tissue samples from the $4^{\text {th }}$ and $5^{\text {th }}$ abdominal segments $(n=10)$ of each farm was carried out as per Kiatpathomchai et al. (2001). The primers used, their sequences, amplification sizes and the PCR protocols are as in Table 1.

\section{Statistical analyses}

Student 't'testwas followed to test the significance of the difference between the various physico-chemical and bacteriological parameters of the pond water samples of two districts. The simple correlation was used to correlate the parameters using the Data Analysis Toolpak in Microsoft Excel.

\section{RESULTS AND DISCUSSION}

\section{Management practices}

The surveyed farms of the Indian Sunderbans followed the intensive monoculture of $P$. vannamei. The farming was done both in leased and own farms. All the surveyed farms of North 24 Parganas district were of a perennial type. The farms of South 24 Parganas district were of $<2$ ha; while in North 24 Parganas district, the farms were $>7$ ha in size. The shape of the pond was almost rectangular with a depth of 1.5-2.0 m. The source water for the farms of South 24 Parganas district was from the Kalnagini River. It was from the Bidyadhari River for the farms of North 24 Parganas district. The ponds of South 24 Parganas district were drained completely, dried for a period of about 7-10 days and scrapped the top layer to remove the sludge before stocking. The farmers used dolomite at $150 \mathrm{~kg} / \mathrm{ha}$ for the treatment of soil. Biosecurity measures were followed, but not strictly in all the farms surveyed.

The SPF post-larvae (PL-10) of $P$. vannamei from the Oceanic shrimp hatchery, Marakkanam, Tamil Nadu and Rank Aqua, Nellore, Andhra Pradesh were stocked. The stocking densities of the farms varied from 50 to $>60 \mathrm{PL} / \mathrm{m}^{2}$. Artificial feed (CPE Blanca) was given to the shrimp as per the standard feeding schedule. The total duration of the crop was 90-120 days.

Table 1 - Primers used for the detection of toxR and AHPND-AP3 genes of Vibrio parahaemolyticus, and the viruses of Penaeus vannamei.

\begin{tabular}{|c|c|c|c|}
\hline Genes & Primers & Size in bp & Reference \\
\hline \multicolumn{4}{|c|}{ Vibrio parahaemolyticus } \\
\hline toxR gene & $\begin{array}{l}\text { toxR - F 5'- GTCTTCTGACGCAATCGTTG - } \\
\text { toxR -R 5' }\end{array}$ & 394 & Kim et al., 1999 \\
\hline \multicolumn{4}{|c|}{ Vibrio parahaemolyticus $\left(\mathrm{Vp}_{\mathrm{AHPND}}\right)$ strain } \\
\hline AHPND- AP3 & $\begin{array}{l}\text { CN2- F 5'- } \\
\text { ATGAGTAACAATATAAAACATGAAAC -3' } \\
\text { CN2-R 5'- GTGGTAATAGATTGTACAGAA -3' }\end{array}$ & 336 & Sirikharin et al., 2014 \\
\hline \multicolumn{4}{|l|}{ Shrimp viruses } \\
\hline WSV $1^{\text {st }}$ step PCR & $\begin{array}{l}\text { P1- F 5'-ATCATGGCTGCTTCACAGAC -3' } \\
\text { P2-R 5'-GGCTGGAGAGGACAAGACAT -3' }\end{array}$ & 982 & Kimura et al., 1996 \\
\hline WSV $2^{\text {nd }}$ step PCR & $\begin{array}{l}\text { P3- F 5'-TCTTCATCAGATGCTACTGC -3' } \\
\text { P4-R 5'-TAACGCTATCCAGTATCACG -3' }\end{array}$ & 570 & Kimura et al., 1996 \\
\hline IHHNV & $\begin{array}{l}\text { IHHNV392F 5'-GGGCGAACCAGAATCACTTA- } \\
\text { 3' } \\
\text { IHHNV392R 5'-ATCCGGAGGAATCTGATGTG- } \\
\text { 3' }\end{array}$ & 500 & Tang et al., 2000 \\
\hline HPV & $\begin{array}{l}\text { H441F 5'- GCATTACAAGAG CCAAGC AG- 3' } \\
\text { H441R 5'-ACACTCAGCCTCTACCTT GT-3' }\end{array}$ & 441 & Phromjai et al., 2002 \\
\hline IMNV & $\begin{array}{l}\text { 4587F 5'-CGACGCTGCTAACCATACAA-3' } \\
\text { 4914R 5'-ACTCGGCTGTTCGATCAAGT-3' }\end{array}$ & 328 & \\
\hline & $\begin{array}{l}4725 \text { NF 5'-GGCACATGCTCAGAGACA-3' } \\
4863 \text { NR 5'-AGCGCTGAGTCCAGTCTTG-3' }\end{array}$ & 139 & oulos \& Lightner, 2006 \\
\hline
\end{tabular}

WSV: White spot virus; IHHNV: Infectious hypodermal and haematopoietic necrosis virus; HPV: Hepatopancreatic parvo-like virus; IMNV: Infectious myonecrosis virus; AHPND: Acute hepatopancreatic necrosis disease (Vibrio parahaemolyticus (Vp $\left.{ }_{\text {AHPND }}\right)$ ). 
The chemicals and immunostimulants used were geolite $\left(6 \mathrm{~kg} / 1000 \mathrm{~m}^{2}\right)$, BioSeize $(15 \mathrm{ml} / \mathrm{kg}$ feed), SuperPS $\left(20 \mathrm{ml} / \mathrm{kg}\right.$ feed), and Superbiotic $\left(600 \mathrm{~g} / 1000 \mathrm{~m}^{2}\right)$. The majority of the farmers used Centella asiatica (Indian pennywort, locally called as Thankuni) leaf juice along with feed (400 leaves $/ 10 \mathrm{~kg}$ feed) to prevent the white faecal cast. Hydrogen peroxide $\left(2.5 \mathrm{~L} / 1000 \mathrm{~m}^{2}\right)$ was used for the improvement of water quality. These aquadrugs use patterns corroborate the observations of the earlier reports (Abraham et al., 2007; Anandaraja et al., 2012a). Immunostimulants have been reported to reduce shrimp mortalities associated with vibriosis and WSV (Balasubramanian et al., 2008; Anandaraja et al., 2012a).

\section{Physicochemical characteristics of the pond water}

The physicochemical characteristics of the pond water of $P$. vannamei culture systems of the Indian Sunderbans are presented in Table 2. The $\mathrm{pH}$ ranged between 7.50 and 9.32. Its level in the farms of South 24 Parganas district was always within the optimum range (6.6-8.5) recommended for shrimp farming (Boyd \& Tucker, 1998). While in North 24 Parganas district farms, the $\mathrm{pH}$ levels were significantly higher $(P<0.01)$ than the recommended level, with a mean of $8.69 \pm 0.42$. Penaeus vannamei is a euryhaline species that can tolerate a wide range of salinities from $<0.5$ to 45 ppt (Bray et al., 1994; Araneda et al., 2008). The pond water salinity of the present study ranged between 8.52 and $14.20 \mathrm{ppt}$, with a mean of $10.58 \pm 2.46$ ppt in North 24 Parganas district farms. On the other hand, its levels were significantly higher $(P<0.01)$ in South 24 Parganas district farms $(20.45 \pm 2.78 \mathrm{ppt})$. The minimum acceptable concentration of total alkalinity is $75 \mathrm{mg} / \mathrm{l}$ and the shrimp may have difficulty in moulting if the total alkalinity is less than $50 \mathrm{mg} / \mathrm{l}$ (Boyd \& Tucker, 1998). The alkalinity levels were above the requirement except the farm located at Krishnanagar, South 24 Parganas district, which recorded frequent mortalities due to WSV. The oxygen dynamics of brackishwater shrimp culture ponds depend on the balance of the autotrophic and heterotrophic production. The DO values were well above the minimum requirement
(3.5 ppm) for shrimp farming (Boyd \& Tucker, 1998), with few farms recorded DO values as high as 15.51 ppm. The DO levels of North 24 Parganas district farms $(12.74 \pm 2.27 \mathrm{ppm})$ were significantly higher $(P<0.01)$, possibly due to the provision of aeration facilities. The results of the water quality parameters corroborate the findings of Priyadarsani \& Abraham (2016) recorded in a low saline shrimp pond of West Bengal. The ammonia-N levels varied in different farms with a maximum of $1.54 \mathrm{ppm}$. The ammonia-N levels in the majority of the farms of the present study exceeded the tolerance limit of $0.1 \mathrm{ppm}$ for $P$. vannamei (Lin \& Chen, 2001). The correlation coefficients $(r)$ between the physicochemical and bacteriological quality parameters of the Penaeus vannamei pond water are presented in Table 4 . The salinity values were significantly but negatively correlated with $\mathrm{pH}, \mathrm{DO}$ and $\mathrm{THC}(\mathrm{P}<0.01)$. The correlation of $\mathrm{pH}$ and $\mathrm{DO}, \mathrm{pH}$ and THC, DO and THC, and THC and PVC were also significant $(P<0.05)$. The WSV infected farm had high ammonia levels possibly because of the wastage of feed due to the reduced feed uptake. In general, the water quality parameters, except ammonia, did not vary substantially during the entire study period, thus, nullifying their influence on the performance of the species.

\section{Bacterial counts in pond water}

The results of the THC, LBC and PVC and the proportion of vibrios in the THC of the $P$. vannamei pond water samples of the Indian Sunderbans are presented in Table 3. In shrimp culture ecosystem, certain bacteria play a negative role as they compete with shrimp for food and oxygen, thus, causing stress and disease. The prescribed range of THCs in the shrimp pond water is $3.00-4.00 \log _{10} \mathrm{cfu} / \mathrm{ml}$ (Tookwinas, 2000). In the present study, the range of THC in the pond water samples was found to be 3.53-6.21 $\log _{10} \mathrm{cfu} / \mathrm{ml}$, well above the prescribed range. Significantly higher bacterial counts $(P<0.05)$ were noted in the farms of North 24 Parganas district due to the intensification in post-stocking management practices, particularly the feeding. ThePVCstoamaximum of $2.00 \log _{10} \mathrm{cfu} / \mathrm{ml}$ are recommended for shrimp

Table 2 - Physicochemical characteristics of the pond water samples of Penaeus vannamei culture systems of the Indian Sunderbans.

\begin{tabular}{lll}
\hline Parameters & Range (Mean \pm standard deviation) & Parameters \\
\hline & South 24 Parganas district farms & $\begin{array}{l}\text { North 24 Parganas district } \\
\text { farms }\end{array}$ \\
\cline { 2 - 3 } $\mathrm{pH}$ & $7.50-7.85(7.76 \pm 0.12)^{\mathrm{a}}$ & $8.20-9.32(8.69 \pm 0.42)^{\mathrm{a}}$ \\
Salinity (ppt) & $16.33-25.30(20.45 \pm 2.78)^{\mathrm{a}}$ & $8.52-14.20(10.58 \pm 2.46)^{\mathrm{a}}$ \\
Dissolved oxygen (ppm) & $4.20-9.43(5.61 \pm 2.25)^{\mathrm{a}}$ & $10.00-15.51(12.74 \pm 2.27)^{\mathrm{a}}$ \\
Alkalinity (ppm) & $70.00-220.00(145.71 \pm 51.59)$ & $140.00-200.00(174.29 \pm 27.60)$ \\
Ammonia (ppm) & $0.08-1.54(0.63 \pm 0.59)$ & $0.01-0.69(0.20 \pm 0.29)$ \\
\hline
\end{tabular}

The values sharing common alphabet (a) within the row differed significantly $(\mathrm{P}<0.01)$. 
Table 3 - Bacterial counts of the pond water samples of Penaeus vannamei culture systems of the Indian Sunderbans.

\begin{tabular}{lll}
\hline Parameters & \multicolumn{2}{l}{ Range (Mean \pm standard deviation) } \\
\cline { 2 - 3 } & South 24 Parganas District farms & North 24 Parganas district farms \\
\hline $\begin{array}{l}\text { Log\# total heterotrophic } \\
\text { bacterial counts (THC)/ml }\end{array}$ & $3.53-4.49(4.06 \pm 0.38)^{\mathrm{a}}$ & $4.85-6.21(5.45 \pm 0.53)^{\mathrm{a}}$ \\
$\begin{array}{l}\text { Log\# presumptive vibrio } \\
\text { counts on TCBS/ml }\end{array}$ & $2.40-4.09(3.42 \pm 0.72)$ & $3.37-4.99(3.98 \pm 0.63)$ \\
$\begin{array}{l}\text { Proportion of vibrios on } \\
\text { TCBS in THC }\end{array}$ & $5.16-80.39(35.84 \pm 29.95)^{\mathrm{a}}$ & $0.95-9.65(4.66 \pm 3.34)^{\mathrm{a}}$ \\
\hline
\end{tabular}

\#: $\log _{10}$ cfu (colony forming units); None of the water samples exhibited luminous bacterial colonies on SWC agar. The values sharing common alphabet (a) within the row differed significantly $(\mathrm{P}<0.05)$.

Table 4 - Correlation coefficient ( $r$ ) between the physicochemical and bacteriological quality parameters of the Penaeus vannamei pond water.

\begin{tabular}{cccccccc}
\hline Parameters & $\mathrm{pH}$ & Salinity & Alkalinity & Ammonia & $\mathrm{DO}$ & $\mathrm{THC}$ & $\mathrm{PVC}$ \\
\hline $\mathrm{pH}$ & 1.000 & $-0.852^{*}$ & 0.214 & -0.407 & $0.894^{*}$ & $0.838^{*}$ & 0.376 \\
Salinity & & 1.000 & -0.472 & 0.492 & $-0.722^{*}$ & $-0.823^{*}$ & -0.485 \\
Alkalinity & & & 1.000 & -0.126 & 0.239 & 0.355 & 0.291 \\
Ammonia & & & & 1.000 & -0.396 & -0.189 & 0.182 \\
DO & & & & & 1.000 & $0.788^{*}$ & 0.174 \\
THC & & & & & & 1.000 & $0.587^{* *}$ \\
PVC & & & & & & & 1.000 \\
\hline
\end{tabular}

DO: Dissolved oxygen ; THC: Total heterotrophic bacterial counts; PVC: Presumptive vibrio counts; *: $\mathrm{P}<0.01 ;{ }^{* *}: \mathrm{P}<0.05$.

culture (Baliao, 2000). In the present study, the PVCs were found to be $2.40-4.99 \log _{10} \mathrm{cfu} / \mathrm{ml}$ on TCBS agar, which was higher than the recommended level. The proportion of vibrios was significantly high $(P<0.05)$ in South 24 Parganas district farms $(35.84 \pm 29.95 \%)$, as the mean salinity was $20.45 \pm 2.78$ ppt. While in North 24 Parganas district farms, it was only $4.66 \pm 3.34 \%$ of the THC. No luminous bacterial growth was noted in the pond water samples, possibly due to the low and fluctuating salinities. Priyadarsani \& Abraham (2013) also recorded comparatively low THC and PVC in a low saline culture system of West Bengal. In contrast, Anandaraja et al. (2017) recorded high levels of THC and PVC in P. vanammei farms of Tamil Nadu, India. Yet, the bacterial counts in the brackishwater ponds of West Bengal were reportedly influenced by the salinity and management practices (Abraham \& Sasmal, 2009).

\section{PCR confirmation of Vibrio parahaemolyticus $\left(\mathrm{Vp}_{\text {AHPND }}\right)$ strain \\ Mild vibriosis was noted in 3 farms as confirmed} by the growth of vibrios from the haemolymph samples on TCBS agar. None of the haemolymph samples exhibited luminescent colonies on SWC agar. A total of $21 \mathrm{~V}$. parahaemolyticus-like strains were isolated from 150 haemolymph samples of shrimp. Vibrio parahaemolyticus strains possess a regulatory gene, toxR and the PCR method targeting the specific toxR gene was used for their identification (Lin et al., 1993; Kim et al., 1999). Out of 21, 20 strains were confirmed to be $V$. parahaemolyticus by the amplification of the toxR gene (Figure 2a, b).

Nevertheless, none of the $20 \mathrm{~V}$. parahaemolyticus strains of the present study was positive for the AHPND-AP3 gene, thus confirming the absence of $V$. parahaemolyticus ( $V p_{\text {AHPND }}$ ) strain or AHPND in the surveyed farms. The results corroborate the findings of Anandaraja et al. (2017) on AHPND in P. vannamei farms of Tamil Nadu, India.
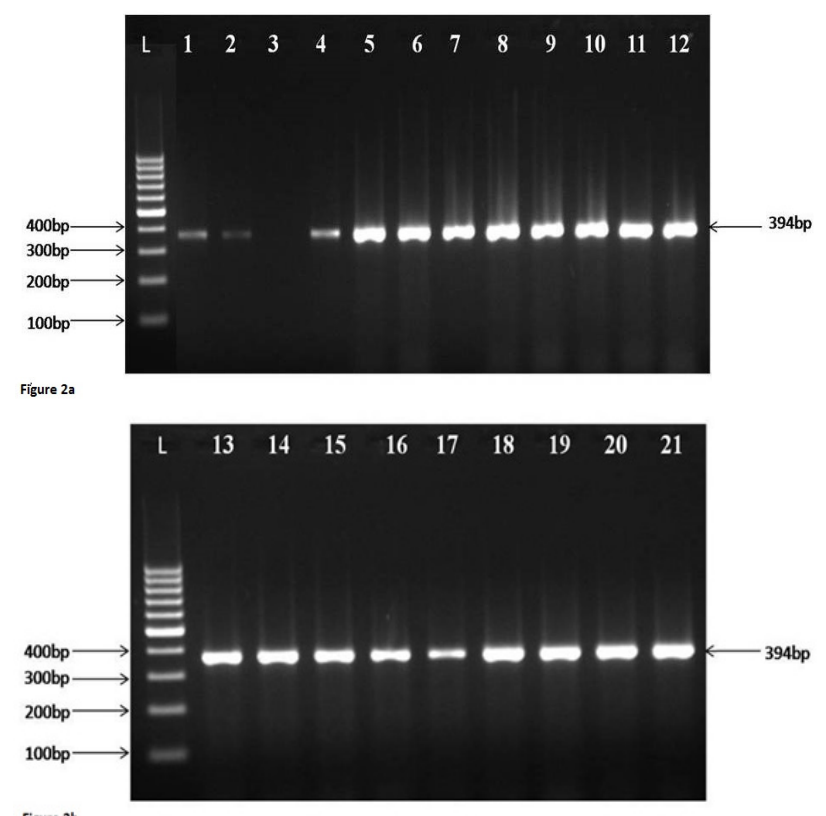

Figure $2 b$

Figure 2 - PCR amplification of toxR gene of Vibrio parahaemolyticus strains. Lane L: 100 bp DNA Molecular weight marker; Lanes (a) 1-12, (b) 13-21: Vibrio parahaemolyticus strains isolated from shrimp haemolymph. 


\section{Detection of shrimp viral diseases and other abnormalities.}

Of the 14 shrimp farm samples examined for WSV, only one farm sample from Krishnanagar, South 24 Parganas district was positive in the $1^{\text {st }}$ and $2^{\text {nd }}$ step PCR (Figures 3 and 4), which recorded the lowest survival rate $(60 \%)$.

All other farm samples were WSV negative. The PCR positive $P$. vannamei samples did not show any typical clinical signs of disease, thus indicating the asymptomatic carrier state. The $P$. vannamei samples from all the farms were negative for IHHNV, IMNV and HPV. These results suggested that WSV is still a problem in shrimp aquaculture in the Indian Sunderbans as was observed in P. monodon (Mishra et al., 2005; Abraham \& Sasmal, 2008; Anandaraja et al., 2012a,b; Dutta et al., 2013) possibly because of the use of poor quality hatchery-raised seeds and over-dependence of pesudoconsultants for seeds and aquadrugs. Muscle cramp condition was noted in two shrimp farms of South 24 Parganas district. No

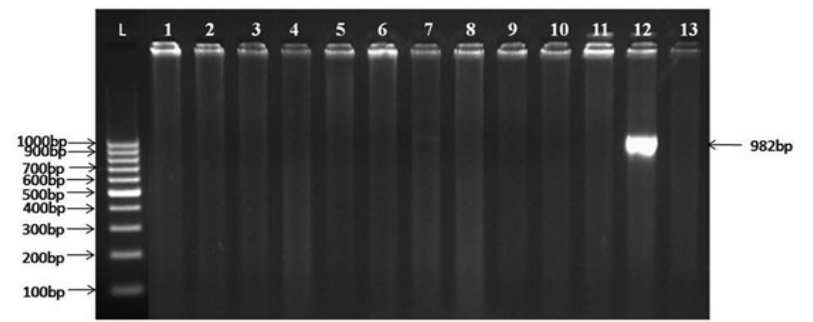

Figure 3 - WSV $1^{\text {st }}$ step PCR. Lane L: 100 bp DNA Molecular weight marker; Lanes 1-13: WSV $1^{\text {st }}$ step PCR products; Lane 7 was weakly positive in $1^{\text {st }}$ step PCR for WSV; Lane 12: WSV positive sample. incidence of Enterocytozoon hepatopenaei (EHP), white faecal syndrome, running mortality syndrome, protozoan infestation, and luminous vibriosis were observed during the survey period (Table 5). The survival rate of $P$. vannamei was $90-95 \%$ in the normal ponds of both districts. The bodyweight of the shrimp was in the range of 25-35 g at the time of harvest. The production of shrimp was 6-7 tonnes/ha in both South and North 24 Parganas districts and some ponds in North 24 Parganas district achieved production up to 15 tonnes/ha. The epidemiological investigation by Anandaraja et al. (2012a) revealed the prevalence of diseased conditions like white spot viral disease, vibriosis, shell problems, gill problems, stunted and uneven growth, white faecal disease, gas bubble disease and yellow discoloration in brackishwater $P$. monodon culture systems of West Bengal, which was more in the traditional system. According to them, the use of known biosecurity measures had a dramatic impact on disease prevalence. The biosecurity measures were not strictly followed due

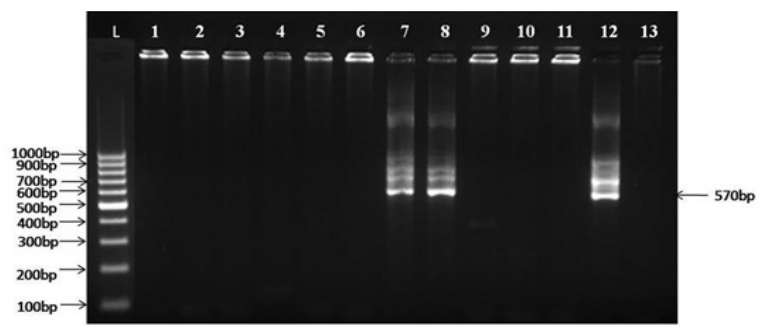

Figure 4 - WSV $2^{\text {nd }}$ step PCR. Lane L: 100 bp DNA Molecular weight marker; Lanes 1-13 WSV ${ }^{\text {nd }}$ step PCR products; Lanes 7 and 8 were positive in $2^{\text {nd }}$ step PCR for WSV; Lane 12: WSV positive sample.

Table 5 - Diseases of Penaeus vannamei cultured in the Indian Sunderbans

\begin{tabular}{|c|c|c|c|}
\hline & Disease & Status & Diagnosis \\
\hline \multicolumn{4}{|c|}{ Existing diseases of $P$. vannamei } \\
\hline A. & Viral & & \\
\hline 1. & White spot virus & $+*(1 / 14)$ & Level 3 \\
\hline 2. & $\begin{array}{l}\text { Infectious hypodermal and haematopoietic } \\
\text { necrosis virus }\end{array}$ & - & Level 3 \\
\hline 3. & Hepatopancreatic parvo-like virus & - & Level 3 \\
\hline B. & Bacterial & & \\
\hline 1. & Vibriosis & $+(3 / 14)$ & $\begin{array}{l}\text { Level } 2 \text { and } \\
3\end{array}$ \\
\hline 2. & Luminous vibriosis & - & Level 2 \\
\hline C. & Parasitic & & \\
\hline 1. & Protozoan infestation & - & Level 1 \\
\hline D. & Environmental & & \\
\hline 1. & Muscle cramp & $+(2 / 14)$ & Level 1 \\
\hline \multicolumn{4}{|c|}{ Emerging diseases of $P$. vannamei } \\
\hline 1. & Infectious myonecrosis virus & - & Level 3 \\
\hline 2. & $\begin{array}{l}\text { Acute hepatopancreatic necrosis disease } \\
\left.\text { (Vibrio parahaemolyticus ( } p_{\text {AHPND }}\right) \text { ) }\end{array}$ & - & Level 3 \\
\hline 3. & White faecal syndrome & $-*$ & Level 1 \\
\hline 4 & Enterocytozoon hepatopenaei & - & Level 1 \\
\hline 5 & Running mortality syndrome & - & Level 1 \\
\hline
\end{tabular}


to the high operational costs and lack of awareness of $P$. vannamei farming practices as well as biosecurity measures. The recent study by Kumaran et al. (2017) concluded that the technical efficiency of the $P$. vannamei farms of West Bengal was relatively low compared to other shrimp-producing states of India. According to Anandaraja et al. (2012a), the use of PCR screening, application of immunostimulants, and strict biosecurity measures play major roles in containing disease outbreaks.

\section{CONCLUSION}

The main limitation in the shrimp farm activities of the Indian Sunderbans is the WSV disease outbreaks in $P$. vannamei, which is a great concern for the majority of farmers. As the development of brackishwater aquaculture in the Indian Sundarbans has been centred around the shrimp farming and the technical efficiencies of the P. vannamei farms were relatively low, special efforts are, therefore, needed to enhance the skills of the West Bengal shrimp farmers in the selection of disease-free seeds, better management practices, biosecurity measures, and optimize the input usage through the capacity enhancement programmes.

\section{ACKNOWLEDGEMENTS}

The research work was supported by the Indian Council of Agricultural Research, Government of India, New Delhi under the Niche Area of Excellence programme vide Grant F. 10(12)/2012-EPD dated 23.03.2012. The authors thank the Vice-Chancellor, West Bengal University of Animal and Fishery Sciences, Kolkata for providing necessary infrastructure facility to carry out the work.

\section{CONFLICT OF INTEREST}

The authors declare that there is no conflict of interest.

\section{REFERENCES}

Abraham, TJ \& Palaniappan, R. 2004. Distribution of luminous bacteria in semi-intensive penaeid shrimp hatcheries of Tamil Nadu, India. Aquaculture 232: 81-90.

Abraham, TJ.; Barman, A; Sasmal, D. \& Nagesh, TS. 2007. A survey on the use of chemicals and biological products in shrimp farms of West Bengal, India. In: Saha, C.; Mal, B.C. and Rao, P.S. (eds.), Proceedings of the All India Seminar on Sustainable Aquaculture for Augmentation of
Export with Special Reference to Environment, Engineering and Value Addition. Agricultural Engineering Division, The Institution of Engineers, West Bengal State Centre, Kolkata, India. 51-55pp.

Abraham, TJ. \& Sasmal, D. 2008. The incidence of different disease conditions in shrimp culture systems of West Bengal with special reference to white spot syndrome virus infection. J Inland Fish. Soc. India 40(2): 1-6.

Abraham, TJ. \& Sasmal, D. 2009. Influence of salinity and management practices on the shrimp (Penaeus monodon) production and bacterial counts of modified extensive brackishwater ponds. Turkish J. Fish. Aquat. Sci. 9(1): 91-98.

Anandaraja, R.; Panigrahi, A. \& Kumar, S. 2012a. Epidemiological investigation of brackishwater culture systems in West Bengal, India. J. Appl. Aquacult. 24(1): 49-59.

Anandaraja, R.; Kumar, S; Sundaray, JK; De, D; Biswas, G. \& Ghosal, TK. 2012b. Haematological parameters in relation to sex, morphometric characters and incidence of white spot syndrome virus in tiger shrimp Penaeus monodon Fabricius, 1798 from Sunderban, West Bengal. Indian J. Fish. 59(4): 169-174.

Anandaraja, R.; Sridhar, R; Balachandran, C; Palanisammi, A; Ramesh, S. \& Nagarajan, K. 2017. Pathogenicity profile of Vibrio parahaemolyticus in farmed Pacific white shrimp, Penaeus vannamei. Fish Shellfish Immunol. 67: 368-381.

APHA/AWWA/WEF, 2012. Standard Methods for Examination of Water and Wastewater. 22nd edition. American Public Health Association, Washington, USA, 1496p.

Araneda, M.; Perez, EP, \& Gasca-Leyva, E. 2008. White shrimp Penaeus vannamei culture in freshwater at three densities: condition state based on length and weight. Aquaculture 283: 13-18.

Balasubramanian, G.; Sarathi, M; Venkatesan, C; Thomas, J. \& Hameed, AS. 2008. Studies on the immunomodulatory effect of extract of Cyanodon dactylon in shrimp, Penaeus monodon, and its efficacy to protect the shrimp from white spot syndrome virus (WSSV). Fish Shellfish Immunol. 25(6): 820-828.

Baliao, DD. 2000. Environment-friendly schemes in intensive shrimp farming. Tigbauan, Iloilo, Philippines: Aquaculture Department, Southeast Asian Fisheries Development Center, 22p.

Boyd, CE. \& Tucker, CA. 1998. Pond Aquaculture Water Quality Management. Klumer Academic Publishers, Boston, 700p.

Bray, WA.; Lawrence, AL. \& Leung-Trujillo, JR. 1994. The effect of salinity on growth and survival of Penaeus vannamei, with observations on the 
interaction of IHHN virus and salinity. Aquaculture 122: 133-146.

Claydon, K.; Tahir, RAH; Said, HM; Lakim, MH. \& Tamat, W. 2010. Prevalence of shrimp viruses in wild Penaeus monodon from Brunei Darussalam. Aquaculture 308(3): 71-74.

Danda, AA.: Sriskanthan, G; Ghosh, A; Bandyopadhyay, J. \& Hazra, S. 2011. Indian Sundarbans Delta: A Vision. World Wide Fund for Nature-India, New Delhi, 40p.

Dutta, S.; Chakrabarty, U.; Mallik, A. \& Mandal, N. 2013. White spot syndrome virus (WSSV) prevalence associated with disease resistance among wild populations of black tiger shrimp, Penaeus monodon (Fabricius). Aquacult. Res. 46(2): 453-461.

FAO, 2013. Report of the FAO/MARD Technical Workshop on Early Mortality Syndrome (EMS) or Acute Hepatopancreatic Necrosis Syndrome (AHPND) of Cultured Shrimp (under TCP/ VIE/3304). Hanoi, Vietnam, 25-27 June 2013, Fisheries and Aquaculture Report No. 1053, FAO, Rome, 54p.

FAO, 2014. The State of World Fisheries and Aquaculture Opportunities and Challenges. FAO, Rome, 243p.

Kiatpathomchai, W.; Boonsaeng, V; Tassanakajon, A; Wongteerasupaya, C; Jitrapakdee, S. \& Panyim, S. 2001. A non-stop, single-tube, semi nested PCR technique for grading the severity of white spot syndrome virus infections in Penaeus monodon. Dis. Aquat. Org. 47: 235-239.

Kim, YB.; Okuda, J; Matsumoto, C; Takahashi, N; Hashimoto, S, \& Nishibuchi, M. 1999. Identification of Vibrio parahaemolyticus strains at the species level by PCR targeted to the toxR gene. J. Clin. Microbiol. 37(4): 1173-1177.

Kimura, T.; Yamanao, K; Heiji, N; Momoyama, K; Hiraoka, M. \& Inouye, K. 1996. Detection of penaeid rod-shaped DNA virus (PRDV) by PCR. Fish Pathol. 31(2): 93-98.

Kumaran, M.; Anand, PR; Kumar, JA; Ravisankar, T; Paul, J; Vasagam, KPK; Vimala, DD. \& Anandaraja, K, 2017. Is Pacific white shrimp (Penaeus vannamei) farming in India is technically efficient? A comprehensive study. Aquaculture 468: 262-270.

Lightner, DV. 1993. Non-infectious diseases of crustacea with an emphasis on cultured penaeid shrimp. In: Couch, JA. and Fourine, FW. (eds.), Advances in Fisheries Science. Pathobiology of Marine and Estuarine Organisms. CRC Press, Boca Raton, 343-358 pp.

Lin, Y. \& Chen, J. 2001. Acute toxicity of ammonia on Litopenaeus vannamei (Boone) juveniles at different salinity levels. J Exp. Mar. Biol. Ecol. 259: 109-119.

Lin, Z.; Kumagai, K; Baba, K; Mekalanos, JJ, \& Nishibuchi, M. 1993. Vibrio parahaemolyticus has a homolog of the Vibrio cholerae toxRS operon that mediates environmentally induced regulation of the thermostable direct hemolysin gene. J. Bacteriol. 175: 3844-3855.

Mishra, SS.; Shekhar, MS. \& Azad, IS. 2005. Concurrent infection with WSSV and MBV in tiger prawn, Penaeus monodon (Fabricius) in West Bengal and their detection using PCR and Dotblot hybridization technique. Indian J. Biotechnol. 4: 506-515.

MPEDA, 2015. Annual Report 2014-2015. Marine Products Export Development Authority, Cochin, India, 256p.

OIE, 2013. Aquatic Animal Health Code. 16th edition. World Organisation for Animal Health, Paris, France, 284p.

Otta, SK.; Arulraj, R; Praveena, EP; Manivel, R; Panigrahi, A. \& Bhuvaneswari, T. 2014. Association of dual viral infection with mortality of pacific white shrimp (Litopenaeus vannamei) in culture ponds in India. Virus Dis. 25(1): 63-68.

Phromjai, J.; Boonsaeng, V; Withyachumnarnkul, B. \& Flegel, TW. 2002. Detection of hepatopancreatic parvovirus in Thai shrimp Penaeus monodon by in situ hybridization, dot blot hybridization and PCR amplification. Dis. Aquat. Org. 51: 227-232.

Poulos BT. \& Lightner DV. 2006. Detection of infectious myonecrosis virus (IMNV) of penaeid shrimp by reverse-transcriptase polymerase chain reaction (RT-PCR). Dis. Aquat. Org. 73: 69-72.

Priyadarsani, L. \& Abraham, TJ. 2013. Ecology of antibiotic-resistant vibrios in traditional shrimp farming system (bhery) of West Bengal, India. J Coast. Life Med. 1(4): 267-274.

Priyadarsani, L. \& Abraham, TJ. 2016. Water and sediment quality characteristics of medium saline traditional shrimp culture system (bheri). J. Fish. 4(1): 309-318.

Raj, RP.; Chandrapal, GD; Manimaran, B; Sinha, MK; Vincent, D; Priya, G. \& Kumar, SR. 2010. Compendium on Introduction and Farming of SPF Litopenaeus vannamei in India. Coastal Aquaculture Authority of India, Chennai, India, 35p.

Ramaiah, N. \& Chandramohan, D. 1993. Ecological and laboratory studies on the rate of luminous bacteria and their luminescence in coastal pollution surveillance. Mar. Poll. Bull. 26: 190-201.

Sirikharin, R.; Taengchaiyaphum, S; Sritunyalucksana, K; Thitamadee, S; Flegel, TW; Mavichak, R. \& Proespraiwong, P. 2014. A new and improved PCR method for detection of AHPND bacteria. A 
new and improved PCR method for detection of AHPND bacteria. Bangkok, Thailand: The Network of Aquaculture Centres in Asia-Pacific. Source: http://www.enaca.org/modules/news/article. php?article_id $=2030$.

Tang, KFJ.; Durand, SV; White, BL; Redman, RM; Pantoja, CR. \& Lightner, DV. 2000. Post-larvae and juveniles of a selected line of Penaeus stylirostris are resistant to infectious hypodermal and hematopoietic necrosis virus infection. Aquaculture 190: 203-210.

Tookwinas, S. 2000. Closed-recirculating Shrimp Farming System. Southeast Asian Fisheries Development Center, Iloilo, Philippines, 27p.

Yang, YT.; Chen, IT; Lee, CT; Chen, CY; Lin, SS; Hor, LI. \& Wang, HC. 2014. Draft genome sequences of four strains of Vibrio parahaemolyticus, three of which cause early mortality syndrome/acute hepatopancreatic necrosis disease in shrimp in China and Thailand. Genome Announcements 2(5): e00816-14.

Submetido: Março/19 Revisado: Novembro/19 Aceito: Novembro/19

Publicado: 06/08/2020 